УДК [902: 572.71] (477.65) «638»

DOI: https://doi.org/10.33782/eminak2019.1(25).280

\title{
КРАНІОЛОГІЯ КІММЕРІЙСЬКОГО НАСЕЛЕННЯ НАДДНІПРЯНЩИНИ
}

\author{
Юрій Долженко \\ Інститут археології Національної академії наук України (Київ, Україна) \\ e-mail: yuriy_dolzhenko@ukr.net \\ ORCID: http://orcid.org/0000-0001-9807-2835
}

у статті за даними краніології дано індивідуальну характеристику черепа з кургану 1, поховання 3, знайденого на території Північного гірничозбагачувального комбінату Кіровоградської області у 2007 . Поховання чоловіка 30-40 років чорногорівського етапу. Паралельно вивчено дискретно-варіативні ознаки. Створено дві серії кіммерійців чорногорівського етапу та збірну вибірку чорногорівського й новочеркаського етапів із залученням даного поховання, яка виявила подібність до черепів скіфської групи з Верхньої Тарасівки.

Ключові слова: кіммерійська культура, краніологія, палеоантропологія, краніометрія, Кіровоградська область, череп, чорногорівський етап

Кіммерійці - найдавніше етнічне утворення на півдні сучасної території України. Про нього ми дізнаємося $з$ ассирійських джерел, з Гомерової «Одіссеї», 3 історії Геродота ${ }^{1}$ й, почасти, з інших античних джерел ${ }^{2}$. Як писав Страбон, перше вторгнення кіммерійців до Еліди й Іонії відбулося за Гомера, або незадовго до його часу (Страбон 1, 2, 9; III, 2, 12)3. Саме до цього періоду відносяться найстаріші згадки про кіммерійців у повісті Гомера про подорож Одіссея 4 о острова Ея, котрий давні автори локалізували у гирлі Ріону (Колхіда). «Сонце тим часом зайшло, - йдеться в «Одіссеї», - і тінями вкрились дороги. Врешті дістались ми течій глибоких ріки Океану. Там розташовані місто й країна людей кіммерійських, хмарами й млою вповиті. Ніколи промінням ласкавим не осяває їх сонце в блакиті ясній світлодайне, чи від землі воно йде у зоряні неба глибини, чи повертається знов до землі з неосяжного неба, - ніч лиховісна там вічно нещасних людей окриває» (Одіссея, XI, 12-19) 5 .

Як зазначив А.I. Тереножкін, кіммерійці, наскільки про них можна судити за залишками поселень і курганними похованнями доби пізньої бронзи, а також похованнями початку залізної доби, були етнічно міцним союзом племен, котрі займали завжди єдину, велику, хоча й мінливу в часі територію на півдні Східної Європиб. Також дослідник підкреслив, що кіммерійці $є$ найдавнішим з відомих за назвою народів, які мешкали в Європі на північ від Чорного моря та Дунаю7.

В ассирійських джерелах про кіммерійців згадується у зв'язку з походами цього народу у межі стародавнього Сходу з сусідніх територій, тому відомостей про почат-

\footnotetext{
1 Геродот. Історії в дев’яти книгах. Київ: Наукова думка, 1993.

2 Даниленко В.Н. До кіммерійської проблеми (у зв'язку з опублікуванням стели із с. Наталівки) // Археологія. 1951. Т. V. С. 218.

3 Тереножкин А.И. Киммерийцы. Київ: Наукова думка, 1976. С. 178.

4 Гомер. Одіссея / Гомер, перекл. Б. Тен. Київ: Дніпро, 1968.

5 Там само.

6 Тереножкин А.И. Указ. соч. С. 212.

7 Ibid. C. 7.
} 
кове розселення кіммерійців бракує. За припущенням В.М. Даниленка, можливо, ассирійці про це достатньо добре знали ${ }^{8}$.

Геродот, говорячи про те, як кіммерійців виганяли скіфи, згадує про р. Аракс як про рубіж, біля якого відбулася перша битва між цими двома народами‥ Босфор Кіммерійський, за Геродотом, безсумнівно, можна ідентифікувати як Керченську протоку. Далі Геродот вказав, що під загрозою скіфської навали у кіммерійців не було єдності щодо того, чи треба обороняти батьківщину, чи слід залишити ії, щоб не загинути, захищаючи «прах». 3 того, що загиблих кіммерійських вождів поховали біля р. Тірас (Дністер), В.М. Даниленко зробив висновок, що саме південно-західне Задніпров'я, точніше південна Наддністрянщина, була тією територією, яку, за функціями у соціальному житті кіммерійців, можна порівнювати зі скіфським Герросом$^{10}$. Отже, за даними В.М. Даниленка, місце проживання кіммерійців визначається принаймні територією між Доном, Керченською протокою, Дністром і південним Дунаєм. Якщо ці області пов'язувати з більш-менш тривалою осілістю кіммерійців, то помітно, що вони певною мірою відповідають тій території, яка у післякіммерійський період одержала назву Скіфії. Саме таку територіальну відповідність і мав на увазі Геродот, коли писав, що на всій території Скіфії раніше жили кіммерійці11.

Б.М. Граков раніше за інших дослідників (ще у кінці 1940-х рр.) писав, що у степовому Причорномор'ї у передскіфський час одночасно мешкали як кіммерійці, так і предки скіфів ${ }^{12}$.

За І.М. Дьяконовим, кіммерійців, які залишили південний степ Східної Європи у першій половині VII ст. до н.е., очолював вождь Лігдаміс (Тугдамме - ассирійським клинописом). На чолі кіммерійців, які вторглись у 679-678 рр. до Ассирії, стояв «цар» Теушпа ${ }^{13}$. Як зазначав дослідник, якщо простежити за іменами царів Лігдаміса, Теушпи та його сина Шандакшатру, то кіммерійці ввійшли до смуги політичної консолідації, міцнішої за союзи племен, лише в умовах міжнародної обстановки VII ст. до н.е. у Малій Азії. Там вони затвердились, за Геродотом, навколо м.Синоп на південному узбережжі Чорного моря, а їхня держава в ассирійських клинописних документах стала називатися Гамірра ${ }^{14}$.

Зі слів Плутарха нам відомо, що лише частина кіммерійців покинула батьківщину, тоді як основна їх маса залишилася на берегах Меотіди (Плутарх, Марій, XI).

На основі нових даних, які, за С.В. Махортихом ${ }^{15}$, показують складнішу, порівняно з версією А.І. Тереножкіна, картину датування кіммерійців, за якою двокільчасті вудила на півдні Східної Європи з'являються вже у IX ст. до н.е., а стременоподібні вудила існували протягом усього передскіфського періоду16.

\footnotetext{
8 Даниленко В.Н. Вказ. праця. С. 218.

9 Геродот. Вказ. праця.

10 Даниленко В.Н. Вказ. праця. С. 218.

11 Геродот. Вказ. праця.

12 Граков Б.М. Скіфи. Київ, 1947.

13 Дьяконов И.М. История Мидии от древнейших времён до конца IV в. до н.э. Москва-Ленинград: Издательство АН СССР, 1956. С. 235-236.

14 Ibid. C. 235.

15 Махортых С.В. Скифы на Кавказе в VII-V вв. до н.э. Дис... канд. ист. наук. Київ, 1987. С. 163-166.

16 Ibid. C. 163-166; Махортих С.В. Культура та історія кіммерійців Північного Причорномор'я». Дис... д-ра іст. наук. 07.00.04. Археологія. Київ, 2008. С. 191.
} 
С.В. Махортих ${ }^{17}$ провів систематизацію та подав типолого-статистичну характеристику поховального обряду та всіх категорій матеріальної культури степового Причорномор'я IX-VII ст. до н.е. За цими даними дослідник стверджує, що кіммерійська культура склалася на основі традицій білозерського та постзрубного населення у степових просторах між Дніпром і Передкавказзям на початку IX ст. до н.е. ${ }^{18}$ Аридизація клімату та погіршення умов існування у степній зоні, за С.В. Махортихом, призвели до того, що культурні утворення фінальної бронзи зникли, а мешканці перейшли до кочового скотарства. Це обумовило зміну матеріальної культури. Розселення давніх кіммерійців у першій половині IX ст. до н.е., за даними С.В. Махортиха, викликало асиміляцію пізніх білозерських общин у Криму, Наддніпрянщині та ДунайськоДніпровському регіоні й остаточне формування культури ранніх кочовиків степового Причорномор'я ${ }^{19}$. Отже, С.В. Махортих на основі специфіки поховального інвентарю, розробив нову періодизацію. Згідно з нею, перший період припадає на першу половину IX ст. до н.е., другий - на середину IX - першу половину VIII ст. до н.е, третій збігається з серединою VIII - початком VII ст. до н.е. ${ }^{20}$

Також археологічні матеріали та загальні закономірності розвитку кочових суспільств дали С.В. Махортиху змогу віднести суспільство кіммерійців Північного Причорномор'я - як два ендогамних племені, що залишили скорчені «чорногорівські» та витягнуті у могилі «новочеркаські» поховання, - до типу «військова демократія» 21.

Кургани Криворіжжя досліджували й досліджують нині такі науковці: O.М. Поль 22 , В.І. Гошкевич23, .М. Сочинський ${ }^{24}$, Б.М. Граков ${ }^{25}$, Л.П. Крилова 26 , О.Б. Будніков, Ю.Я. Рассамакін ${ }^{27}$, В.В.Отрощенко ${ }^{28}$, С.І. Лукьяшко ${ }^{29}$, С.А.Скорий ${ }^{30}$, С.В. Махортих ${ }^{31}$, В.А. Ромашко ${ }^{32}$, а також 0.0. Мельник ${ }^{33}$ та I.О. Стеблина 34.

З 1971 по 2010 рр. охоронні розкопки провадив Криворізький історикокраєзнавчий музей. За цей час археологи дослідили 90 курганів, де виявили 621 по-

\footnotetext{
17 Махортих С.В. Вказ. праця. С. 191.

18 Ibid. C. 379.

19 Ibidem.

20 Ibidem.

21 Ibidem.

22 Каталог коллекции древностей А.Н. Поль в Екатеринославе. Киев: Кульженко, 1893. Вып. 1 / сост. К. Мельник. 1893.

${ }^{23}$ Fabritsius I.V. Tzareva mogila // Eurosia Septent riokolis Antigua. Helsiki, 1929. P. 126-134.

24 Лагодовська О.Ф. Пам'ятки усатівського типу // Археологія. 1953. Вип. VIII. С. 101.

25 Граков Б. Інформаційний звіт Нікопольської археологічної експедиції за 1946 р. // Археологічні пам'ятки УРСР. 1949. Т. II. С. 112-115; Граков Б.Н. Скифы. Москва, 1971.

26 Крилова Л.П. Археологічні розкопки стародавніх курганів на Криворіжжі в 1964-1966 pp. // Наш край. Дніпропетровськ: Промінь, 1971. С. 18-31.

27 Рассамакін Ю.Я., Будников О.Б. Проблеми раннього степового енеоліту у світлі вивчення нових пам’яток // Археологія. 1993. № 3. С. 128-140.

28 Отрощенко В.В. О погребениях черногоровского типа в Нижнем Подонье // Историкоархеологическое исследование в Азове и на Нижнем Дону в 1993 г. Азов, 1994. Вып. 13. С. 103-117. 29 Лукьяшко С.И. Предскифский период на Нижнем Дону. Азов: Азовский краеведческий музей, 1999.

30 Скорый С.А. Киммерийцы в украинской Лесостепи. Киев, Полтава: Археология, 1999.

31 Махортих С.В. Вказ. праця.

32 Ромашко В.А. Передскифский период в пограничье лесостепи и степи Днепровского Левобережья (XII - начало VII вв. до н.э.) Автореф. дис... канд. ист. наук. 07.00.04: Археология. Киев, 1990.

33 Мельник А.А., Ромашко В.А. Киммерийские погребения Криворожья // Исследования по археологии Поднепровья. Днепропетровск: ДГУ. С. 71-76.

34 Мельник 0.О., Стеблина I.O. Кургани Криворіжжя. Кривий Ріг, 2012.
} 
ховання. Деякі комплекси й поховання, за даними О.О. Мельника й I.О. Стеблини, було опубліковано у збірниках Інституту археології Національної академії наук України (далі - IАНАНУ), Дніпропетровського національного університету, «Археологічних відкриттях». Більший масив інформації осів у формі звітів в архівах IA НАНУ, фондах Криворізького музею й у монографії «Кургани Криворіжжя»35.

Завдяки 0.0. Мельнику до лабораторії відділу біоархеології ІАНАНУ потрапило поховання 3 з кургану 1, яке дослідники ${ }^{36}$ датували передскіфським періодом.

За даними автора розкопу 0.0. Мельника ${ }^{37}$, курган 1 розташований за 0,3 км на Пн. від північного борту Ганівського кар'єру Північного ГЗК і за 80 м на захід від старої бетонної дороги Кривий Ріг-Жовті Води. Висота кургану перед початком робіт становила 8,2 м. Поховання 3 - кіммерійське, розташовувалось за 11,0 м на ПдСх від УЦ $\left(\mathrm{A}=115^{\circ}\right)$ на глибині 3,9 м. Померлий, людина похилого віку, лежав скорчено на лівому боці, з розворотом на спину, головою на ПдС ${ }^{38}$. Руки зігнуті у ліктях під прямим кутом, лікті на одній лінії. Кістки лежали разом, це вказує на те, що корпус розвернувся, коли сухожилля вже не утримували кісток. У тазових суглобах ноги зігнуті під тупим (близьким до прямого) кутом, гомілкові кістки разом і паралельні стегну правої ноги, стопи разом. Одна бронзова прямокутна пластинка лежала на правій скроневій кістці черепа, друга - біля лівої орбіти. У носовій порожнині - залишки шкіри, просякнутої окислами бронзи. Праворуч, біля правого крила тазу, на дні, знайдено бронзове поясне кільце із залишками шкіряного паска. На відстані 0,2 м від лівого плеча кістяка, під стіною підбою, на боці, горлом у бік черепа, лежав ліпний круглобокий горщик. При розборі скелета 0.0. Мельник та I.O.Стеблина під лівою скроневою кісткою знайшли третю бронзову пластину 3 залишками шкіряного ремінцяз9.

Краніологію чорногорівського та новочеркаського типів досліджувала С.І. Круц40. Вона виявила, що населення, яке залишило чорногорівські поховання, було мезодоліхокранним, з помірно широким, високим, мезогнатним, добре профільованим обличчям і вузьким носом подібно до скіфських груп Нижньої Наддніпрянщини (Широке, Кам'янка-Дніпровська, кургани Керченського півострова). Черепи з новочеркаських поховань різко відрізняються від чорногорівських мезобрахікранією та широким обличчям і знаходять аналогії з брахікранним компонентом могильника Фронтове-1, черепами з таврських поховань Криму, карасукських серій II-I тис. до н.е.41 Однак С.I. Круц наголосила, що ці висновки потребують перевірки на більш представницьких матеріалах ${ }^{42}$.

\section{Методологічні засади дослідження.}

Індивідуальну краніометричну характеристику чоловічого черепа, піднятого 2007 р. $з$ кургану 1, поховання 3 під час розкопок експедиції (КРАE-2007) на тери-

\footnotetext{
35 Ibidem.

36 Ibid. C. 171.

37 Ibid. C. $139-142$.

38 Ibid. С. 141. Рис. 95.1.

39 Ibid. C. 141.

40 Круц С.И. Антропологические данные к киммерийской проблеме // Археологія. 2002. № 4. С. 1328; Круц С.И. Скифы степей Украины по антропологическим данным. Курганы Украины. Т. 5. Киев-Берлин, 2017. С. 85-91.

${ }^{41}$ Круц С.И. Скифы степей Украины... С. 85-91.

42 Ibid. C. 91.
} 
торії Північного гірничозбагачувального комбінату Кіровоградської області ${ }^{43}$, наведено у таблиці № 1. Паралельно вивчалися дискретно-варіативні ознаки, які віддзеркалюють генетичні зв'язки у популяції. Розвиток потиличного відростка (sguama ossis occipitalis) відмічався за М.М. Герасимовим ${ }^{44}$. Стертість зубів відмічали за схемою Д.Бротвелла 45 . Ступінь облітерації швів і вік визначалися за схемою Г. Валуа ${ }^{46}$. Назомалярний і зигомаксилярний кути горизонтального профілювання обличчя вираховувалися за допомогою номограми, оскільки більшість дослідників користуються саме цією сіткою47. Визначення краніометричної точки лямбда провадилось за методом Л.Бакстона й Г. Моранта ${ }^{48}$. За методикою Н.А. Абіндера вимірювалися назомалярний і зигомаксилярний кути ${ }^{49}$. Позаяк в етнічній антропології, зокрема у краніоскопії, існують деякі розбіжності щодо методичного підходу до вивчення неметричних ознак на черепі людини 50 , у цій роботі застосовуються відразу дві краніоскопічні методики: О.Г. Козінцева й Е.Г. Беррі та Р.Я. Беррі ${ }^{51}$, яку апробувала А.А. Мовсесян ${ }^{52}$.

\section{Поховання 3 з кургану 1.}

Збереженість черепа добра, відсутня нижня частина потилиці, але краніологічні точки opisthion i basion збереглися. Візуально склепіння помірно масивне. Череп представлений з нижньою щелепою, яка складалася з двох частин. М'язовий рельєф потилиці помірний, потиличний горб розвинений добре (3 бали), соскоподібні відростки - великі (3 бали). Лоб нахилений, лобних і потиличних горбів не помітно. Надперенісся розвинуте помірно (2 бали). Така морфологія й ознаки на тазових кістках вказують на чоловічу стать похованого. Черепні шви з внутрішньої сторони закриті, із зовнішньої почалася їх облітерація. Стертість зубів слабка (3 бали). За морфологічними ознаками можна визначити, що чоловік помер у 30-40 років.

Поздовжній і поперечний діаметри черепної коробки помірні, за індексом череп мезокранний $(77,8)$. Абсолютний висотний діаметр (від краніологічної точки базіон), середній. Висотно-поздовжній покажчик помірний (ортокранія), висотнопоперечний індекс середній (метріокранія, помірно високий череп). Довжина осно-

\footnotetext{
43 Мельник 0.О., Стеблина І.О. Вказ. праця. С. 139-142.

44 Герасимов М.М. Восстановление лица по черепу. Москва: ТИЭ. Новая серия. Т. 28. 1955.

45 Brothwell D.R. Digging up Bones. London, 1972.

46 Vallois H.V. Laduree de la viechez l'home fossile // L'Anthropologie. 1937. № 47. P. 499-532.

47 Алексеев В.П., Дебец Г.Ф. Краниометрия. Методика антропологических исследований. Москва: Наука, 1964. С. 53. Рис. 14.

48 Buxton L.H.D., Morant G.D. Essential craniological technique // Journal Royal Anthropological Institute. 1933. V. 63. P. 19-47.

49 Абиндер Н.А. Трансверзальная уплощенность лицевого скелета // Труды института этнографии АН СССР. Т. 50. 1960. С. 153-178.

50 Козинцев А.Г. Дискретные признаки на черепах эпохи бронзы из Южной Сибири // К проблемам методики изучения краниологического полиморфизма // Исследования по палеоантропологии и краниологии СССР. Москва, 1980. С. 75-99; Козинцев А.Г. Этническая краниоскопия: расовая изменчивость швов черепа современного человека. Ленинград: Наука, 1988; Моисеев В.Г. Опыт интеграции четырех систем антропологических признаков (краниометрии, краниоскопии, одонтологии и дерматоглифики) // Палеоантропология, этническая антропология, этногенез: К 75-летию Ильи Иосифовича Гохмана. Санкт-Петербург: Изд-во МАЭ РАН, 2004. С. 187.

51 Berry A.C., Berry R.J. Epigenetic Variationinthe Human Cranium // Journal Anat. 1967. V. 101. P. 361-379. 52 Мовсесян А.А. Фенетический анализ в палеоантропологии в связи с проблемами расо- и этногенеза. 03.00.14. Дис... д-ра биол. наук. Москва, 2005.
} 
ви черепа велика, горизонтальна окружність через краніометричну точку офріон помірна. До дуже малого класу належить лобна хорда, тож висота вигину чола дуже мала. Широтні розміри лобної кістки малі у фронтальному та великі - у дорсальному відділі. Лобно-поперечний індекс малий $(65,7)$. Профіль лоба від назіона великий, а від глабели - помірний. Ширина основи черепа за стандартними абсолютними розмірами дуже велика, ширина потилиці - помірна (див. табл. 1).

Табл. 1. Індивідуальна краніометрична характеристика чоловічого черепа кіммерійської культури з могильника КРАЕ розкопок 2007 р. на території Північного гірничозбагачувального комбінату Кіровоградської обл.

\begin{tabular}{|c|c|c|}
\hline $\begin{array}{l}\text { № за Map- } \\
\text { тіном }\end{array}$ & Ознаки $\quad$ Рік та № поховання & $\begin{array}{c}2007 \text { p. } \\
\text { пох. } 3\end{array}$ \\
\hline & Вік & $30-40$ \\
\hline 1. & Повздовжній діаметр & 180,0 \\
\hline 1в & Повздовжній діаметр від офріона & 178,0 \\
\hline 8. & Поперечний діаметр & 140,0 \\
\hline 17. & Висотний діаметр basion-bregma & 133,0 \\
\hline 20. & Вушна висота porion-porion-bregma & 110,9 \\
\hline 9. & Найменша ширина чола & 92,0 \\
\hline 10. & Найбільша ширина чола & 122,0 \\
\hline 5. & Довжина основи черепа & 104,0 \\
\hline 11. & Ширина основи черепа & 133,0 \\
\hline 12. & Ширина потилиці & 108,0 \\
\hline 29. & Лобна хорда & 103,5 \\
\hline 30. & Тім'яна хорда & 106,2 \\
\hline 31. & Потилична хорда & 91,0 \\
\hline $23 a$. & Горизонтальна окружність через ofrion & 505,0 \\
\hline 24. & Поперечна дуга po-br-po & 310,0 \\
\hline 25. & Сагітальна дуга & 349,0 \\
\hline 26. & Лобна дуга & 120,0 \\
\hline 27. & Тім’яна дуга & 117,0 \\
\hline 28. & Потилична дуга & 112,0 \\
\hline FS & Висота вигину лоба & 22,0 \\
\hline \multirow[t]{5}{*}{ OS } & Висота вигину потилиці & 29,0 \\
\hline & Надперенісся ( за Мартіном 1-6) & 3 \\
\hline & Надбрівні дуги (1-3) & 2 \\
\hline & Зовнішній потиличний бугор (1-5) & 3 \\
\hline & Соскоподібний виросток (1-3) & 3 \\
\hline
\end{tabular}




\begin{tabular}{|c|c|c|}
\hline & Нижн.край грушоподібного отвору & Anthr \\
\hline & Передньо-носова ость (за Брока 1-5) & 4 \\
\hline 45. & Діаметр вилиць & 137,0 \\
\hline 40. & Довжина основи обличчя & 107,0 \\
\hline 48. & Верхня висота обличчя & 78,0 \\
\hline 47. & Повна висота обличчя & 133,0 \\
\hline 43. & Верхня ширина обличчя & 107,0 \\
\hline 46. & Середня ширина обличчя & 98,0 \\
\hline 60. & Довжина альвеолярної дуги & 60,0 \\
\hline 61. & Ширина альвеолярної дуги & 63,8 \\
\hline 62. & Довжина піднебіння & 55,0 \\
\hline 63. & Ширина піднебіння & 35,1 \\
\hline 55. & Висота носа & 57,0 \\
\hline 54. & Ширина носа & 25,8 \\
\hline 51 & Ширина орбіти від $m f$ & 43,9 \\
\hline \multirow[t]{5}{*}{52.} & Висота орбіти & 31,4 \\
\hline & Бімалярна ширина fmo-fmo & 100,5 \\
\hline & Висота назиона над fmo-fmo & 16,7 \\
\hline & Зигомаксилярна ширина $z m-z m$ & 98,0 \\
\hline & Висота субспінале над zm-zm & 22,0 \\
\hline SC & Симотична ширина & 9,0 \\
\hline SS & Симотична висота & 5,0 \\
\hline MC & Максилофронтальна ширина & 21,0 \\
\hline MS & Максилофронтальная висота & 6,0 \\
\hline DC & Дакриальная ширина & 24,0 \\
\hline \multirow[t]{4}{*}{ DS } & Дакріальна висота & 8,5 \\
\hline & Ширина виличної кістки & 60,0 \\
\hline & Висота вигину виличної кістки & 15,0 \\
\hline & Глибина іклової ямки & $-4,0$ \\
\hline 77. & Назомалярний кут & $140,3^{\circ}$ \\
\hline$\angle \mathrm{Zm}$. & Зигомаксилярний кут & $131,2^{\circ}$ \\
\hline \multirow[t]{2}{*}{32} & $\angle$ профіль чола від n & $85,0^{\circ}$ \\
\hline & $\angle$ від gl & $74,0^{\circ}$ \\
\hline 72 & $\angle$ загально лицевий & $80,0^{\circ}$ \\
\hline 73 & $\angle$ сер. частини обличчя & $80,0^{\circ}$ \\
\hline 74 & $\angle$ альвеолярної частини обличчя & $75,0^{\circ}$ \\
\hline
\end{tabular}




\begin{tabular}{|c|c|c|}
\hline 75 & $\angle$ нахил лицьових кісток & $56,0^{\circ}$ \\
\hline $75(1)$ & $\angle$ випинання носа & $34,0^{\circ}$ \\
\hline \multicolumn{3}{|c|}{ Індекси } \\
\hline 8:1 & Черепний індекс & 77,8 \\
\hline $17: 1$ & Висотно-повздовжній покажчик I & 73,9 \\
\hline $17: 8$ & Висотно-поперечний покажчик I & 95,0 \\
\hline $20: 1$ & Висотно-повздовжній покажчик II & 61,6 \\
\hline $20: 8$ & Висотно-поперечний покажчик II & 79,2 \\
\hline 9:10 & Лобний покажчик & 75,4 \\
\hline 10:8 & Коронарно-поперечний & 87,1 \\
\hline 9:8 & Лобно-поперечний покажчик & 65,7 \\
\hline $29: 26$ & Індекс вигину лобної кістки & 86,2 \\
\hline $30: 27$ & Індекс вигину тім'яної кістки & 90,7 \\
\hline $48: 45$ & Верхньолицевий покажчик & 56,9 \\
\hline $48: 17$ & Вертикальний фаціо-церебральний індекс & 58,6 \\
\hline $40: 5$ & Покажчик виступання обличчя & 102,9 \\
\hline $45: 8$ & $\begin{array}{l}\text { Горизонтальний } \\
\text { фаціо-церебральний індекс }\end{array}$ & 97,9 \\
\hline $9: 45$ & Лобно-виличний індекс & 67,2 \\
\hline $52: 51$ & Орбітний індекс & 71,5 \\
\hline $54: 55$ & Носовий індекс & 45,3 \\
\hline DS:DC & Дакріальний індекс & 35,4 \\
\hline SS:SC & Симотичний індекс & 55,6 \\
\hline MS:MC & Максило-фронтальний індекс & 28,6 \\
\hline $63: 62$ & Піднебінний індекс & 63,8 \\
\hline $10: 45$ & Лобно-виличний індекс & 106,3 \\
\hline
\end{tabular}

Обличчя мезогнатне, дуже високе та широке. Діаметр вилиць можна вважати великим, на межі з помірними розмірами - 137,0 мм. За верхньолицевим індексом, обличчя вузьке (лептен). За загальним лицевим індексом $(97,1)$ обличчя також вузьке (лептопрозопія). Альвеолярний прогнатизм невиразний, кут альвеолярної частини - помірний.

Орбіти великої ширини та малої висоти, за покажчиком $(75,1)$ низькі (хамеконхія). У расово-діагностичному відношенні велике значення приділяється будові перенісся та ступеню випинання носових кісток. Ніс дуже високий і помірно широкий, за покажчиком - вузький (лепторинія), дуже сильно випнутий. Носові кісточки помірно широкі та дуже високі. За симотичним покажчиком перенісся дуже високе, але за дакріальним - помірно високе. Нижній край грушоподібного отвору має антропінну форму передньоносових ямок (Anthropinae). Передня носова ость велика (4 бали).

Назомалярний і зигомаксилярні кути помірні, що свідчить про середньо 
профільоване обличчя на верхньому та нижньому рівнях. Іклова ямка малої глибини (-4). У цілому, за краніологічними ознаками, чоловічій череп із поховання 3 належить до великої європеоїдної раси.

\section{Внутрішньогруповий аналіз.}

Для порівняння з черепом «кіммерійця» (чорногорівський етап, IX-VIII ст. до н.е.) з Кіровоградської області, поховання 3, (КРАЕ-3), піднятим 2007 р., ми відібрали 4 чоловічі черепи з поховань, що належать до Чорногорівської групи (див. табл. 2), виявлені переважно на степовому Лівобережжі Нижньої Наддніпрянщини: Любимівка, кург. 56, поховання 2 (Херсонська обл.); Висока могила, поховання 5 (Запорізька обл.); Степове, кург. 9, пох. 2 (Запорізька обл.); Софіївка, могильник, пох. 3, а також один череп Новочеркаської групи (VIII-VII ст. до н.е.) з Василівки (Херсонська обл.) пох. 8 кургану 153.

У плані розмежування матеріалу автор орієнтується на роботи С.I. Круц ${ }^{54}$, але археологічна концепція щодо чорногорівського 55 та новочеркаського 56 етапів на сьогодні дещо змінилась і є дискусійною. Короткий історіографічний огляд з приводу чорногорівської культури у міжріччі Базавлук-Солена-Чортомлик подала М.М. Дараган у розділі III ${ }^{57}$.

У названих черепів збереглися такі краніометричні ознаки: поздовжній і поперечний діаметр черепної коробки, вилична ширина, висота та ширина орбіти (див. табл. 3).

Виходячи з таблиць 3-4, можна зробити тривимірний графік (рис. 2), але він буде не дуже інформативним, позаяк третя головна компонента (далі - ГК) (11,9\% загальної дисперсіі) має тільки 0,598 власних чисел, тобто менша, ніж 1,000. Черепи переважно роз'єдналися за ГК I, на яку припадає 60\% загальної дисперсії. Найважливішими виявились такі краніометричні ознаки з додатними значеннями ГК: ширина орбіти, вилична хорда, поперечний діаметр черепної коробки та з від'ємними значеннями - висота орбіти. Досліджуваний чоловічий череп отримав додатні значення за даною компонентою $(0,583)$ і виявив певну подібність до черепа зі Степового-2 (0,208).

На ГК II припадає 24,8\% загальної дисперсії, яка розподіляє черепи переважно за однією ознакою - поздовжнім діаметром черепної коробки.

За даною компонентою досліджуваний череп отримав великі від'ємні значення $(-1,477)$ і вдруге статистично подібний до черепа зі Степового-2 $(-1,157)$.

\footnotetext{
53 Круц С.И. Скифы степей Украины по антропологическим данным. Курганы Украины. Т. 5. КиевБерлин, 2017. Табл. 1.

54 Ibid. C. 14-15. Табл. 1; С. 85-99.

55 Отрощенко В.В. Особенности погребений черногоровской группы // Проблемы скифосарматской археологии Северного Причерноморья. Тезисы докладов. Запорожье, 1989. С. 111112.

56 Махортих С.В. Вказ. праця; Ромашко В.А. Кіммерійські скорчені поховання новочеркаської групи // Археологія. 1992. № 3. С. 60-65; Шрамко Б.А. Киммерийский вклад в культуру скифской эпохи // Проблемы эпохи бронзы юга Восточной Европы: тезисы докладов конференции. Донецк, 1979. С. 12-13.

57 Черных Л.А., Дараган М.Н. Курганы эпохи энеолита - бронзы междуречья Базавлук-СоленаяЧертомлык. Київ: Олег Філюк, 2014. С. 344-366.
} 


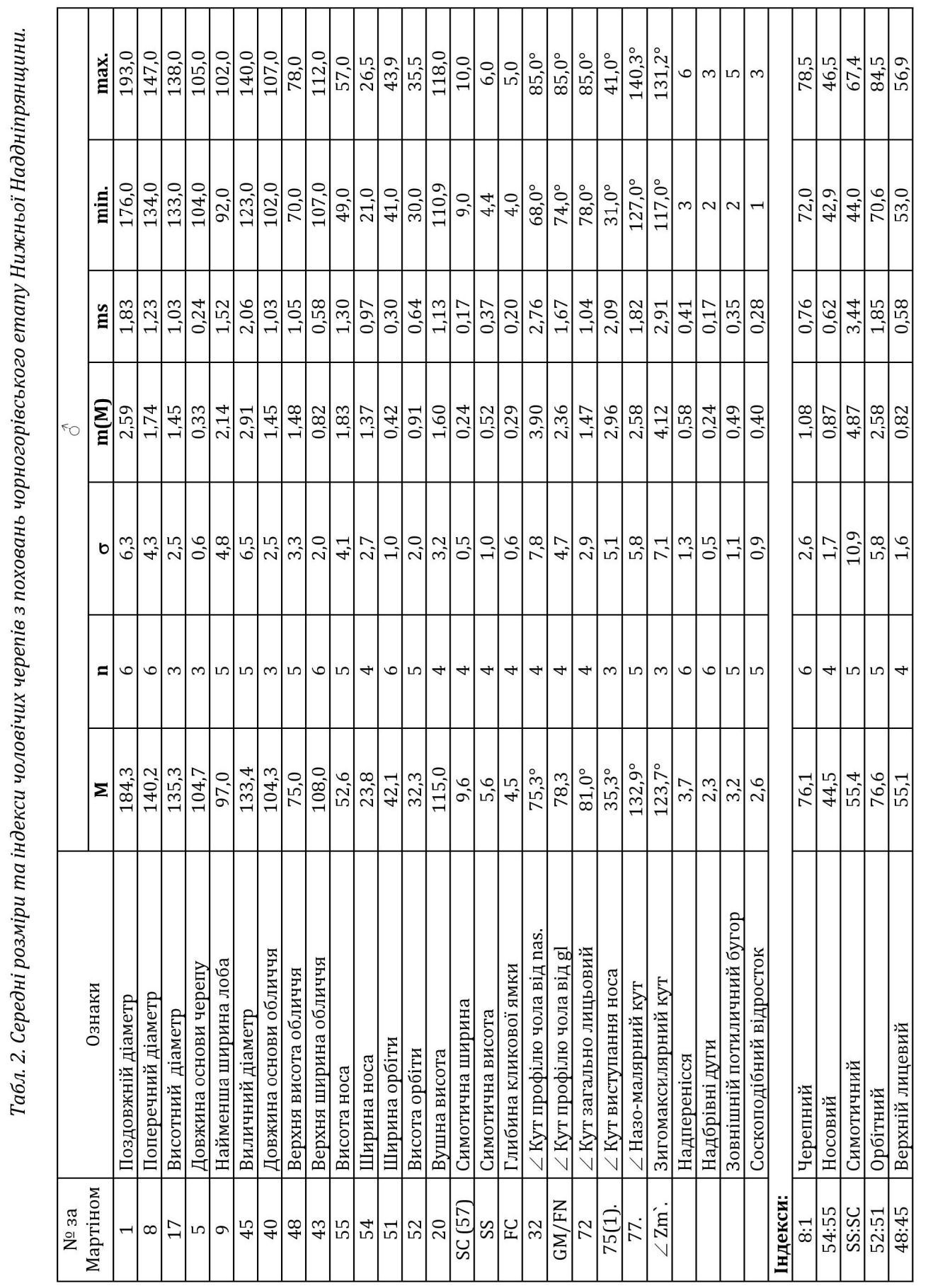

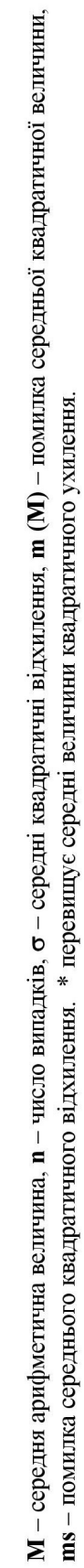


Табл. 3. Елементи перших трьох ГК для шести чоловічих черепів за п'ятьма краніометричними ознаками.

\begin{tabular}{|l|c|c|c|}
\hline \multicolumn{1}{|c|}{ Ознака } & \multicolumn{3}{c|}{ त } \\
\cline { 2 - 4 } & ГК 1 & ГК 2 & ГК 3 \\
\hline 1. Повздовжній діаметр & -0.326 & $\mathbf{0 . 9 1 4}$ & -0.208 \\
\hline 8. Поперечний діаметр & $\mathbf{0 . 8 5 8}$ & 0.475 & -0.005 \\
\hline 45. Виличний діаметр & $\mathbf{0 . 8 6 7}$ & 0.295 & 0.349 \\
\hline 51. Ширина орбіти від $m f$ & $\mathbf{0 . 9 3 7}$ & -0.246 & 0.117 \\
\hline 52. Висота орбіти & $\mathbf{- 0 . 7 3 4}$ & 0.183 & 0.648 \\
\hline Власні числа & 3.012 & 1.243 & 0.598 \\
\hline Внесок в загальну дисперсію (\%) & 60.240 & 24.860 & 11.958 \\
\hline
\end{tabular}

ГК - Головна компонента

Табл. 4. Значення Головних Компонент (ГК).

\begin{tabular}{|l|c|c|c|}
\hline \multirow{2}{*}{\multicolumn{1}{|c|}{ Поховання }} & \multicolumn{3}{|c|}{ ठ } \\
\cline { 2 - 4 } & ГК 1 & ГК 2 & ГК 3 \\
\hline КРАЕ-3 & 0.583 & -1.477 & 0.482 \\
\hline Висока могила 5 & -0.672 & 0.790 & 1.347 \\
\hline Степове 2 & 0.208 & -1.157 & -0.294 \\
\hline Софіївка 3 & -1.595 & -0.174 & -0.725 \\
\hline Любимівка 2 & -1.563 & 1.038 & -0.432 \\
\hline Василівка 8 & 3.039 & 0.980 & -0.378 \\
\hline
\end{tabular}

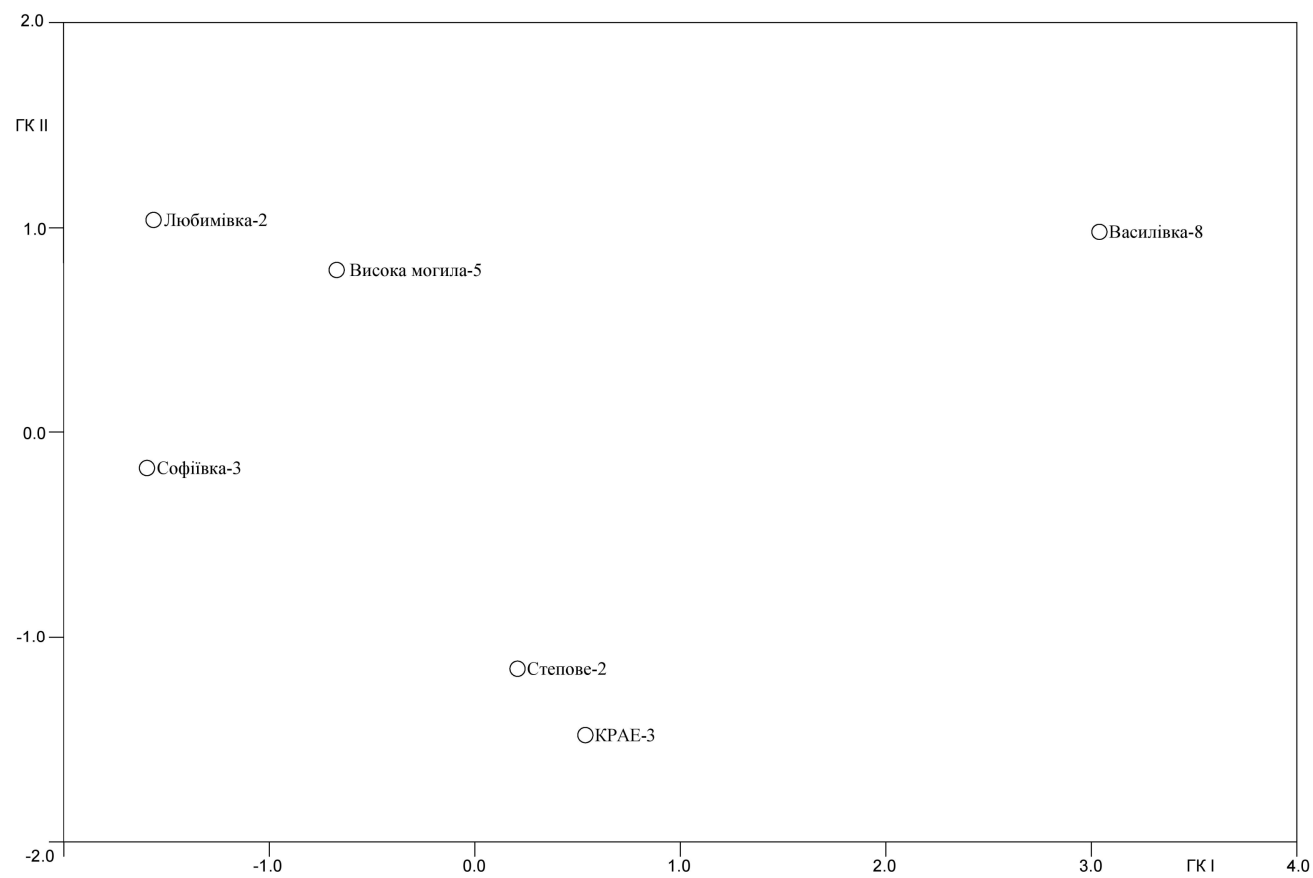

Рис. 1. Розташування шести чоловічих черепів кіммерійців у просторі ГК І і ГК ІІ (за п'ятьма краніометричними ознаками).

Цифри вказують на шифр черепів, які дослідила С.І. Круц. 
На рисунку 1 можна простежити розташувалися черепів у двомірному просторі. Досліджуваний череп - у нижній центральній частині координатного поля, де поряд розташувався мезокранний череп із пох. 2 Запорізької обл. (Степове, курган 9). Найвіддаленішим виявився брахікранний великий череп з широким обличчям із пох. 8 Новочеркаської групи - Василівка (Херсонська обл.), курган 1.

За даними кластерного аналізу, найменша відстань - також між указаними черепами КРАЕ-3 і Степове-2 (0,920), вже на першому кроці кластеризації з п'яти.

Табл. 5. Коефіцієнти кореляції між краніометричними ознаками.

\begin{tabular}{|c|c|c|c|c|c|}
\hline Ознаки & 1 & 8 & 45 & 51 & 52 \\
\hline 1. Повздовжній діаметр & \multirow{5}{*}{$\begin{array}{l}- \\
0.141 \\
-0.088 \\
-\mathbf{0 . 5 3 3} \\
0.273\end{array}$} & \multirow{5}{*}{$\begin{array}{l}- \\
0.855 \\
0.679 \\
-0.535\end{array}$} & \multirow{5}{*}{$\begin{array}{l}\overline{\mathbf{0 . 7 5 5}} \\
-0.375\end{array}$} & \multirow{5}{*}{$\overline{-0.645}$} & \multirow[b]{5}{*}{-} \\
\hline 8. Поперечний діаметр & & & & & \\
\hline 45. Виличний діаметр & & & & & \\
\hline 51. Ширина орбіти & & & & & \\
\hline 52. Висота орбіти & & & & & \\
\hline
\end{tabular}

За ГК III досліджуваний череп, отримавши додатне значення $(0,482)$, дуже слабко подібний до черепа зі Степового-2 $(-0,294)$.

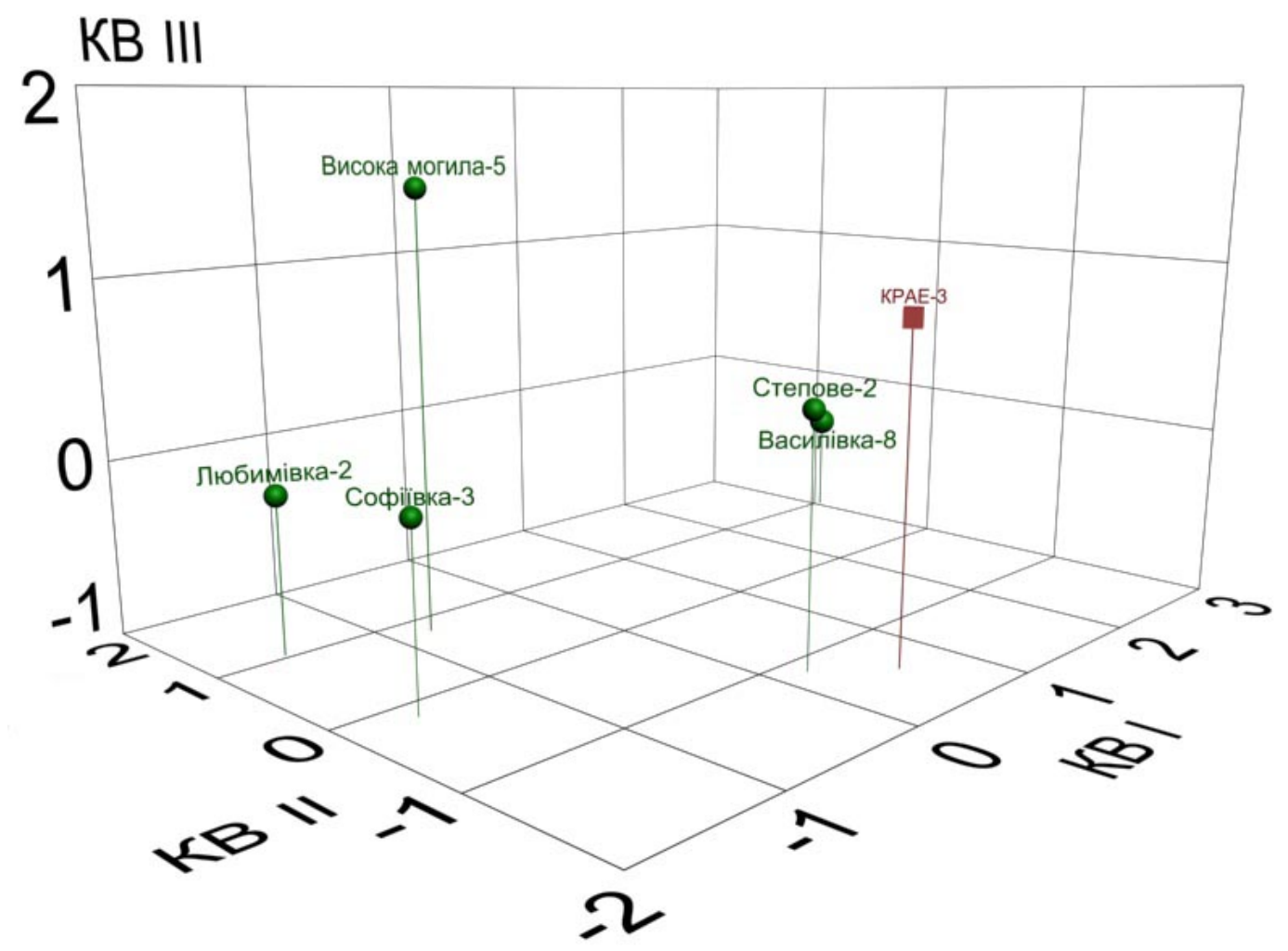

Рис. 2. Розташування шести чоловічих черепів кіммерійців у тривимірному просторі (за п'ятьма краніометричними ознаками). 
Отже, череп кіммерійця (чорногорівський етап, IX-VIII ст. до н.е.) 3 Кіровоградської обл., пох. 3, (КРАЕ-3) найближче подібний до чоловічого черепа зі Степового Запорізької обл.: кург. 9, пох. 2 (за п’ятьма краніологічними ознаками).

У подальшому було створено групу з шести черепів чорногорівського етапу (IXVIII ст. до н.е.), яка складається з чотирьох мезокранних і двох доліхокранних черепів. У цілому характеризується мезокранною, помірно високою черепною коробкою як за лінійним розміром, так і за висотно-поздовжнім (ортокранія) та висотно-поперечним індексом (метріокранія). Довжина основи черепа - велика. Лоб помірно широкий, обличчя - мезогнатне, високе, помірно широке за виличним діаметром (133,4 мм), але за верхнім лицевим індексом $(55,9)$ його можна вважати вузьким (лептен). На верхньому та середньому рівні обличчя дуже сильно профільоване. Відносна ширина орбіт помірна (мезоконхія). Ніс вузький (лепторинія), кут його випинання - дуже великий $\left(35,3^{\circ}\right)$. Перенісся високе.

\section{Міжгруповий багатовимірний аналіз.}

Розглянемо подібність серії кіммерійців чорногорівського етапу (IX-VIII ст. до н.е.) до синхронних груп.

До канонічного аналізу58 залучалися такі 13 ознак та один індекс: поздовжній, поперечний і висотний діаметри черепа $(b-b r)$, найменша ширина лоба, виличний діаметр, висота обличчя, висота та ширина орбіт, висота та ширина носа, назомалярний і зигомаксилярний кути, симотичний індекс і кут випинання носа. Результати подано у таблицях 3 і 4.

Важливо визначити місце досліджуваної вибірки серед відомих серій пізньобронзового та ранньозалізного періодів і, насамперед, з'ясувати, наскільки вони подібні до відомих скіфських матеріалів Північного Причорномор'я. У зв'язку з тим, що кіммерійські поховальні пам'ятки поширені на великій території - від Дунаю до Волгй59, - для порівняння залучено дані 34 чоловічих краніологічних серій IX-VIII ст. до н.е., які досліджували різні вчені (рис. 3, 4).

Скіфські групи: Верхня Тарасівка60; Інгулецька група61; Гайманове поле ${ }^{62}$; Носакі63; Мамай Гора64; Каховка65; Медвин ${ }^{66}$; Неаполь Скіфський67; Нікопольстрой68;

\footnotetext{
58 Дерябин В.Е. Курс лекций по многомерной биометрии для антропологов. Москва: МГУ, 2008.

59 Дубовская 0.3. О локальных особенностях в инвентаре черногоровских погребений // Тезисы докладов областного научно-практического семинара «Проблемы охраны и исследования памятников археологии в Донбассе». Донецк, 1987. С. 75-77.

60 Круц С.И. Палеоантропологические материалы из кургана Желтокаменка // Древности степной Скифии. Киев, 1982. С. 151-157.

61 Круц С.И. Палеоантропологические материалы... Київ, 1982.

62 Ефимова С.Г. Соотношение лесостепных и степных групп населения Европейской Скифии по данным краниологии // Скифы и сарматы в VII-III вв. до н.э.: палеоэкология, антропология и археология. Москва: Ин-т археол. РАН, 2000. С. 39-44.

63 Круц С.И. Скифы степей... С. 25-26.

64 Литвинова Л.В. Антропологический материал из могильника Мамай-Гора // Андрух С.И. Могильник Мамай-Гора. Запорожье: [Б.и.], 2001. Кн. 2. Прил. 1. С. 246-271.

65 Круц С.И. Скифы степей... С. 29.

66 Круц С.И. Антропология Стеблевского могильника (к вопросу о физическом типе населения лесостепи в скифское время) Прил. 2 // Скорый С.А. Стеблев: Скифский могильник в Поросье. Киев, 1997. С. 91-116.

67 Зиневич Г.П. Очерки палеоантропологии Украины. Киев: Наукова думка, 1967. С. 128, Табл. 17; Кондукторова Т.С. Населення Неаполя Скіфського за антропологічними даними // Матеріали 3 антропології України. Вип. 3. 1964. С. 32-71.

68 Зиневич Г.П. Указ. соч. С. 128, Табл. 17.
} 
Акташ ${ }^{69}$; Миколаївка на Дністрі70; Кам'янка Дніпровська ${ }^{71}$; Миколаївка Козацька72; Золота Балка73; Завітне ${ }^{74}$; Північне Західне Причорномор'я75; Самаро-Орельське межиріччя76; Фронтове-177; Керченський курган ${ }^{78}$.

Групи зрубної культури: Зрубники України ${ }^{79}$; Степне 80 ; Ябалакла, Башкирія, Лузанівка, Хрящівка, Лісостепове Поволжя, Саратовська обл. Сумарно, ВолгоградськоАстраханська обл. Сумарно, Крива Лука, хутір Ясирів, Ростовська обл., Лівобережжя Дніправ1; Правобережжя Дніпра82.

Культура Ноа (Румунія) ${ }^{83}$. Полтавкинська культура $84 ;$ Пепкінський курган85; Старі Бедражі86. Багатопружкова культура: Калфа ${ }^{87} ;$ КБК 88.

За I канонічним вектором (далі - КB) (40,6\% загальної мінливості), спостерігається тяжіння чоловічої кіммерійської групи (рис. 3), яка отримала від'ємні значення даної КВ $(-0,340)$ до черепів з Пепкінського кургану $(-0,551)$, а також, певною мірою, до черепів Мамай Гори $(-0,200)$.

69 Покас П.М., Назарова Т.А., Дяченко В.Д. Материалы по антропологии Акташского могильника // Бессонова С.С., Бунятян Е.П., Гаврилюк Н.А. Акташский могильник скифского времени в Восточном Крыму. Киев: Наукова думка, 1988. С. 118-144.

70 Великанова М.С. Палеоантропология Прутско-Днестровского междуречья. Москва: Наука, 1975.

71 Жиляева-Круц С.И. Черепа из скифских погребений Керченской экспедиции 1964-1967 гг. // Древности Восточного Крыма. Киев: Наукова думка, 1970. С. 180-189.

72 Кондукторова Т.С. Физический тип людей нижнего Приднепровья на рубеже нашей эры: по материалам могильника Николаевка-Казацкое. Москва, 1979. С. 36-40. Табл. 1.

${ }^{73}$ Ibid. C. 71-72. Табл. 12.

74 Зіневич Г.П. До антропології могильника біля с. Завітне в Криму // Матеріали з антропології України. Вип. 5. Київ: Наукова думка, 1971. С. 111-121.

75 Литвинова Л.В. Антропологические материалы скифской культуры из Северо-Западного Причерноморья // Ольвия-200. Тезисы докладов международной конференции посвященной двухсотлетию археологического открытия Ольвии (5-9 сентября 1994 г., с. Парутино). Николаев, 1994. С. 79-80.

76 Круц С.И. Скифы степей... С. 66. Табл. 10-11; Мельник Л.А. Антропологическая характеристика населения Самаро-Орельского междуречья в эпоху бронзы // Древности Степного Поднепровья (III-II тыс. до н.э.). Днепропетровск: Изд. ДГУ, 1982. С. 76-88.

77 Круц С.И. Скифы степей Украины по антропологическим данным. Курганы Украины. Т. 5. КиевБерлин, 2017. С. 109-112.

78 Жиляева-Круц С.И. Черепа из скифских погребений Керченской экспедиции 1964-1967 гг. // Древности Восточного Крыма. Киев: Наукова думка, 1970. С. 180-189.

${ }^{79}$ Круц С.И. Палеоантропологические исследования Степного Поднепровья (эпоха бронзы) Киев: Наукова думка, 1984. С. 62-65. Табл. 23.

80 Ibidem.

81 Шевченко А.В. Антропология населения южнорусских степей в эпоху бронзы // Антропология современного и древнего населения европейской части СССР. Ленинград: Наука, 1986. С. 190-193. Табл. 27.

82 Круц В.А. Позднетрипольские памятники Среднего Поднепровья. Киев: Наукова думка, 1977.

С. 140-176; Шевченко А.В. Указ. соч. Табл. 27.

83 Великанова М.С. Указ. соч. С. 39-40, 88.

84 Глазкова Н.М., Чтецов В.П. Палеоантропологические материалы Нижневолжского отряда Сталинградской экспедиции // Материалы и исследования по археологии. 1960. № 78. С. 285-292; Шевченко А.В. Указ. соч. С. 190-193. Табл. 27.

85 Герасимова М.М. Черепа из погребений срубной культуры в Среднем Поволжье // Краткие сообщения института истории материальной культуры. 1958. Вып. 71. С. 72-77; Шевченко А.В. Указ. соч. С. 190-193. Табл. 27.

86 Великанова М.С. Указ. соч. С. 39-40. Табл. 21.

87 Круц С.И. Указ. соч. Табл. 17.

88 Ibid. C. 48-51. 
За КВ II (31,6\% загальної мінливості) чоловіча серія отримала малі від'ємні значення вектора $(-0,069)$ та знайшла аналогії з могильником із Калфи $(-0,040)$ i, меншою мірою, з Каховкою $(-0,005)$.

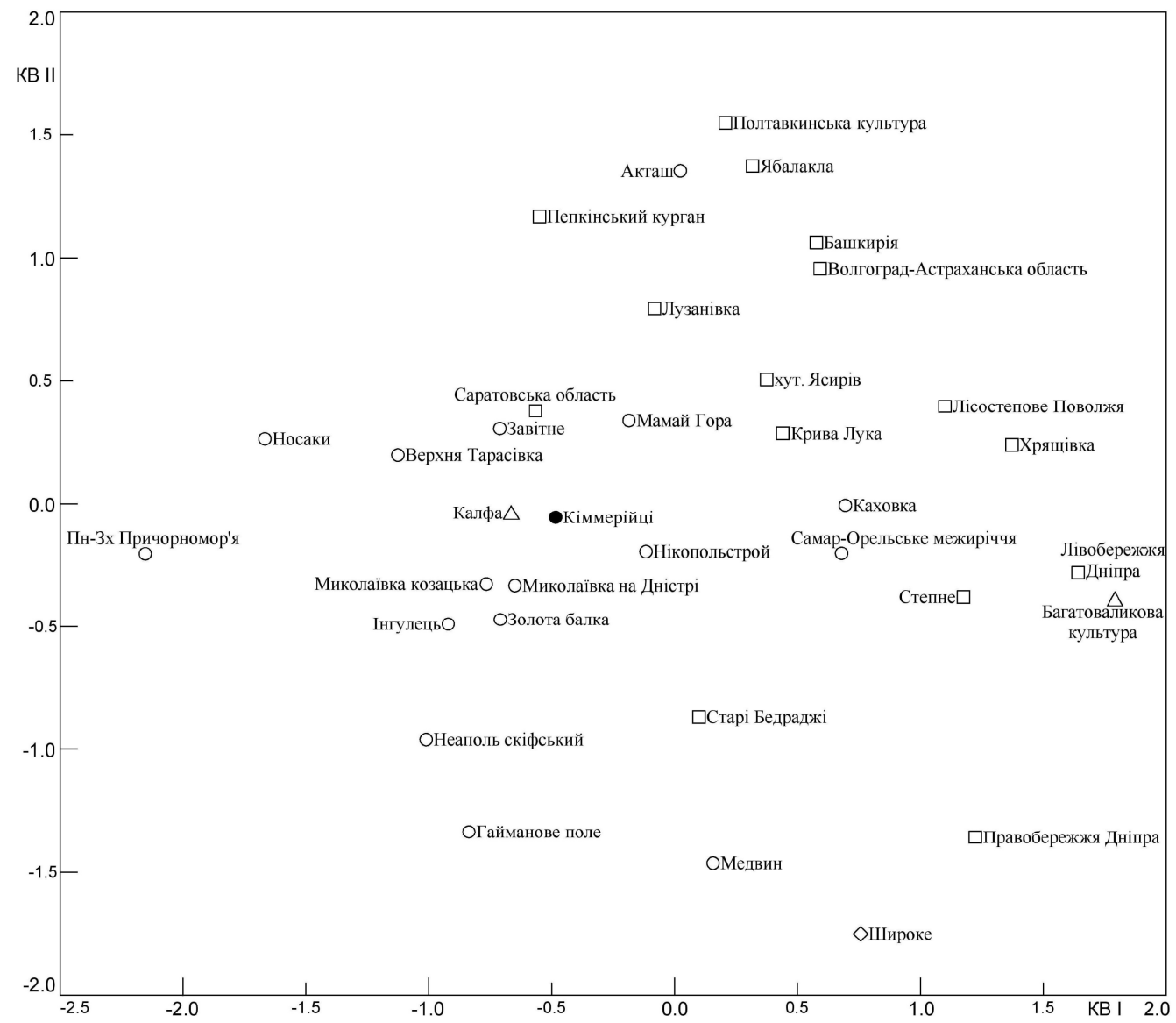

Рис. 3. Результати канонічного аналізу. Зіставлення 35 чоловічих груп IX-VIII cm. до н.е. з вибіркою кіммерійців із шести черепів (чорногорівський етап) у просторі I-II KB. оскіфи; г-зрубна культура; $\mathbf{\Delta}$ - багатопружкова культура; $\diamond-$ білозерська культура.

За КВ III (27,7\% загальної мінливості) досліджувана група (рис. 4), отримавши помірні від'ємні значення вектора $(-0,835)$, певною мірою виявила статистичну подібність до черепів із Золотої Балки $(-0,833)$ та Миколаївки Козацької $(-0,763)$.

За кластерним багатовимірним аналізом (загальна дистанція 3,925), вибірка 3 чорногорівського етапу тяжіє до черепів з Нікопольстрою на п'ятому кроці кластеризації (дистанція -2,722). Також до одного кластеру потрапляють Миколаївка Козацька, Золота Балка, Миколаївка на Дністрі.

Загалом, чорногорівські черепи у просторі КВ I та КВ II подібні як до могильника багатопружкової культури Калфа, так і до скіфської групи Нікопольстрой.

На другому етапі дослідження, після об’єднання черепів у загальну серію з чорногорівського та новочеркаського етапів (табл. 6), до вже описаних черепів чорногорівського етапу долучилися два черепи новочеркаського етапу з Нижньої 
Наддніпрянщини (Василівка, курган 1, пох. 8; Останіно, курган 23, пох. 13). Таким чином, загальна група кіммерійців із восьми черепів Нижньої Наддніпрянщини характеризується мезокранною, помірно високою черепною коробкою. Обличчя мезогнатне, помірно широке та високе, різко профільоване. Орбіти низькі, ніс вузький, перенісся високе, ніс випнутий дуже сильно.

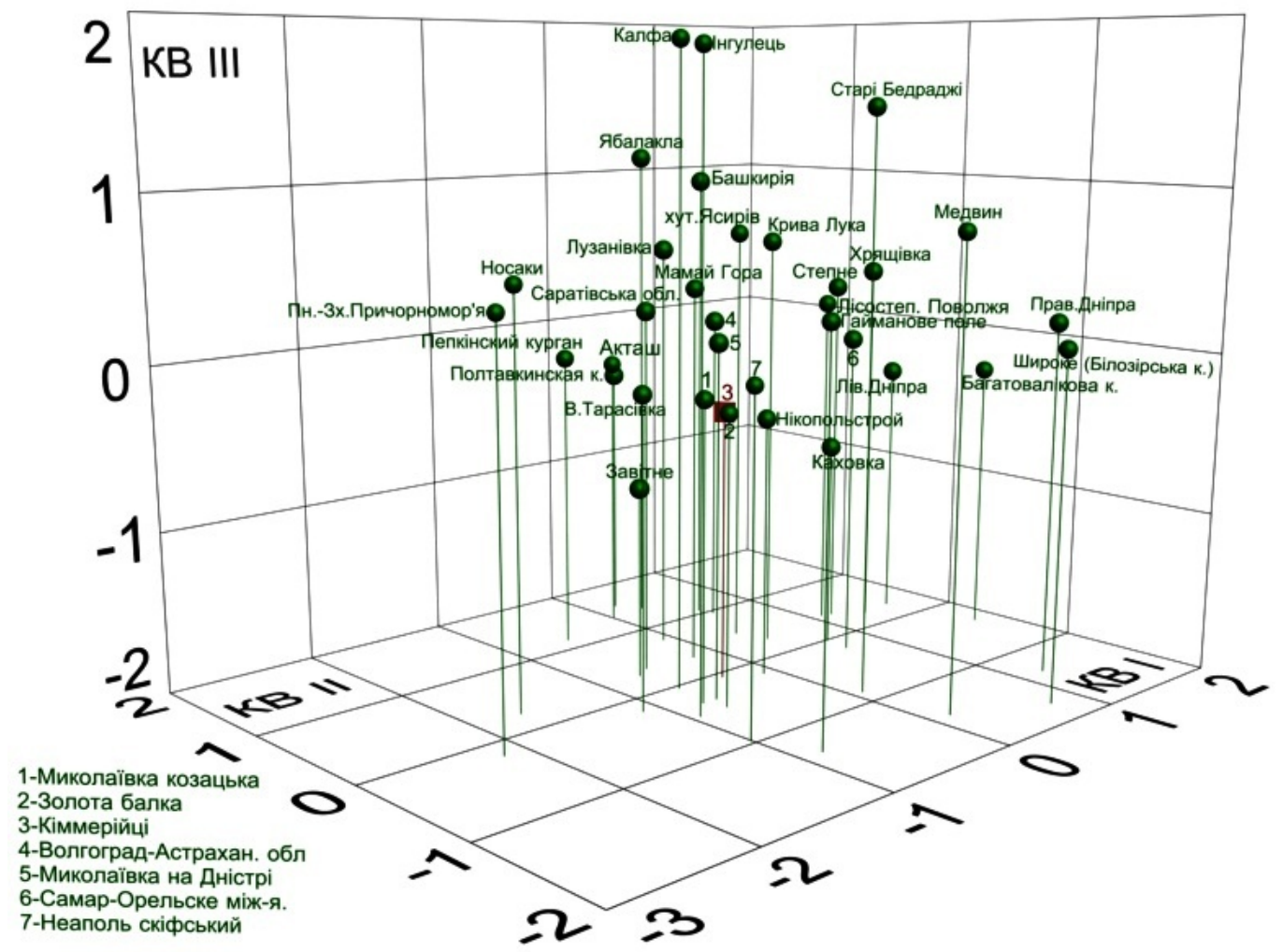

Рис. 4. Результати канонічного аналізу. Зіставлення 35 чоловічих груп IX-VIII cm. до н.е. $з$ вибіркою кіммерійців (чорногорівський етап).

Для порівняння методом канонічного аналізу залучено дані описаних 35 чоловічих краніологічних серій IX-VIII ст. до н.е. (рис. 5,6 ).

За КВ I (41,1\% загальної мінливості), чоловіча загальна кіммерійська група, котра отримала великі від'ємні значення даного КВ $(-1,134)$, тяжіє до черепів з Верхньої Тарасівки $(-1,110)$ та, меншою мірою, до Неаполя Скіфського $(-1,010)$.

За КВ II (31,3\% загальної мінливості) чоловіча серія (рис. 5) отримала помірні додатні значення вектора $(0,292)$ і знайшла аналогії з могильником із Мамай Гори $(0,293)$ та Хрящівки $(0,287)$.

За КВ III (27,5\% загальної мінливості) досліджувана група, отримавши від'ємні значення вектора $(-0,823)$, певною мірою виявила статистичну подібність до черепів із Золотої Балки $(-0,822)$.

За кластерним багатовимірним аналізом (загальна дистанція 3,964), спостерігається тяжіння вибірки з чорногорівського та новочеркаського етапу до черепів з Верхньої Тарасівки на п'ятому кроці кластеризації (дистанція -2,706). Також до одного кластеру з ними увійшла вибірка із Завітного. 


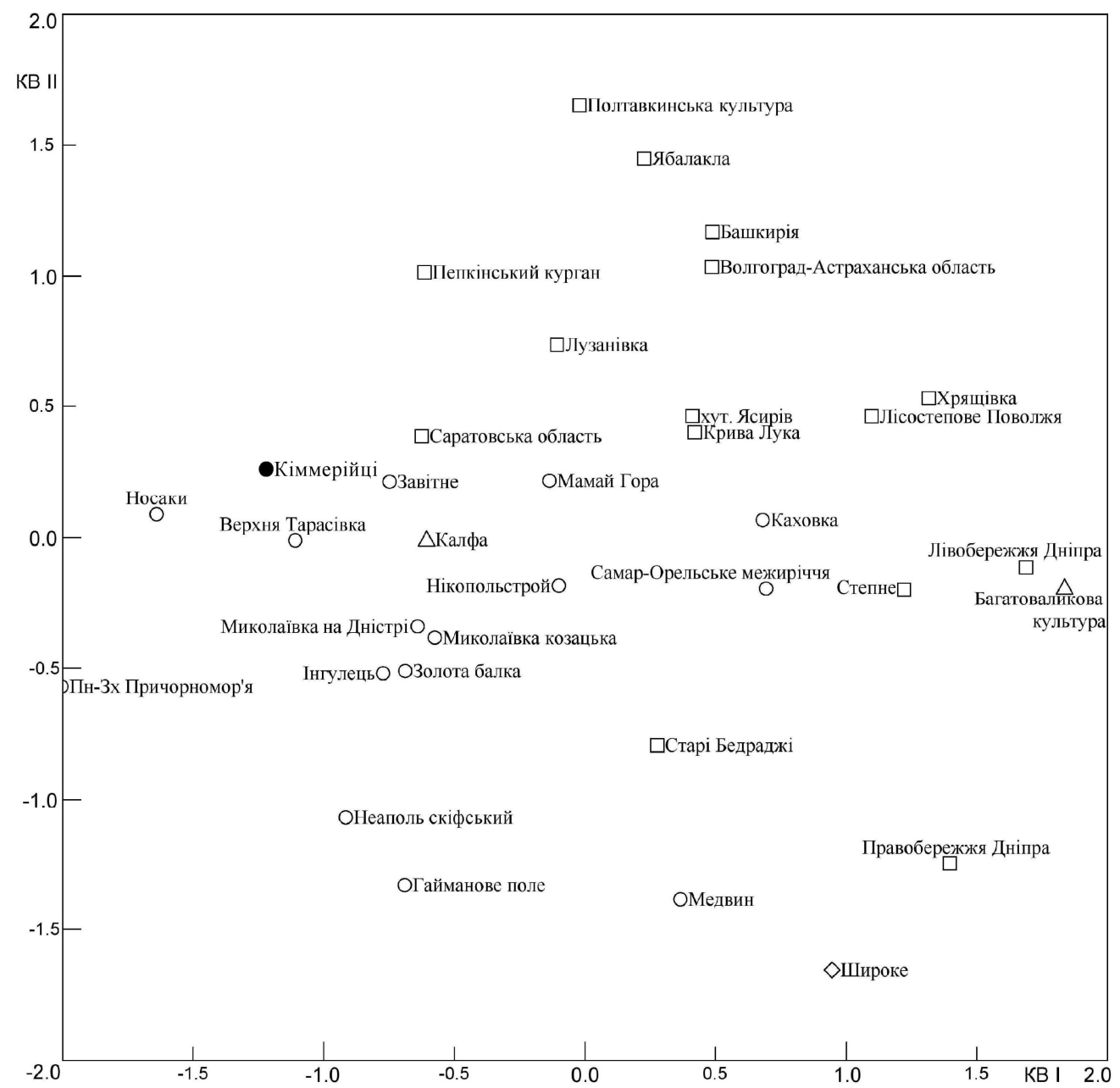

Рис. 5. Результати канонічного аналізу. Зіставлення 35 чоловічих груп IX-VIII cm. до н.е. 3 загальною вибіркою кіммерійців із восьми черепів (чорногорівський і новочеркаський етапи) у просторі КВ I-II.

У цілому досліджувана збірна кіммерійська група подібна до черепів скіфів 3 Верхньої Тарасівки. Ця подібність пояснюється припущенням С.В. Махортиха ${ }^{89}$ про те, що після сутичок скіфів з місцевим кіммерійським і кобанським населенням настав період встановлення мирних стосунків. Також, на думку дослідника, не виключено, що скіфи зайняли ключові райони Предкавказзя та разом з кіммерійцями почали брати участь у передньоазійськіх походах. У кінці VIII і протягом значної частини VII ст. до н.е. скіфів і кіммерійців доволі часто розрізняли передньоазійські джерела, в яких вони виступали як дві самостійні політичні сили ${ }^{90}$.

Виявлено, що результати багатовимірних аналізів із залученням черепів спільно чорногорівського та новочеркаського етапів, а також черепів чорногорівського етапів окремо, різняться слабо.

${ }^{89}$ Махортих С.В. Вказ. пр. С. 384.

90 Ibid. C. 384-385. 


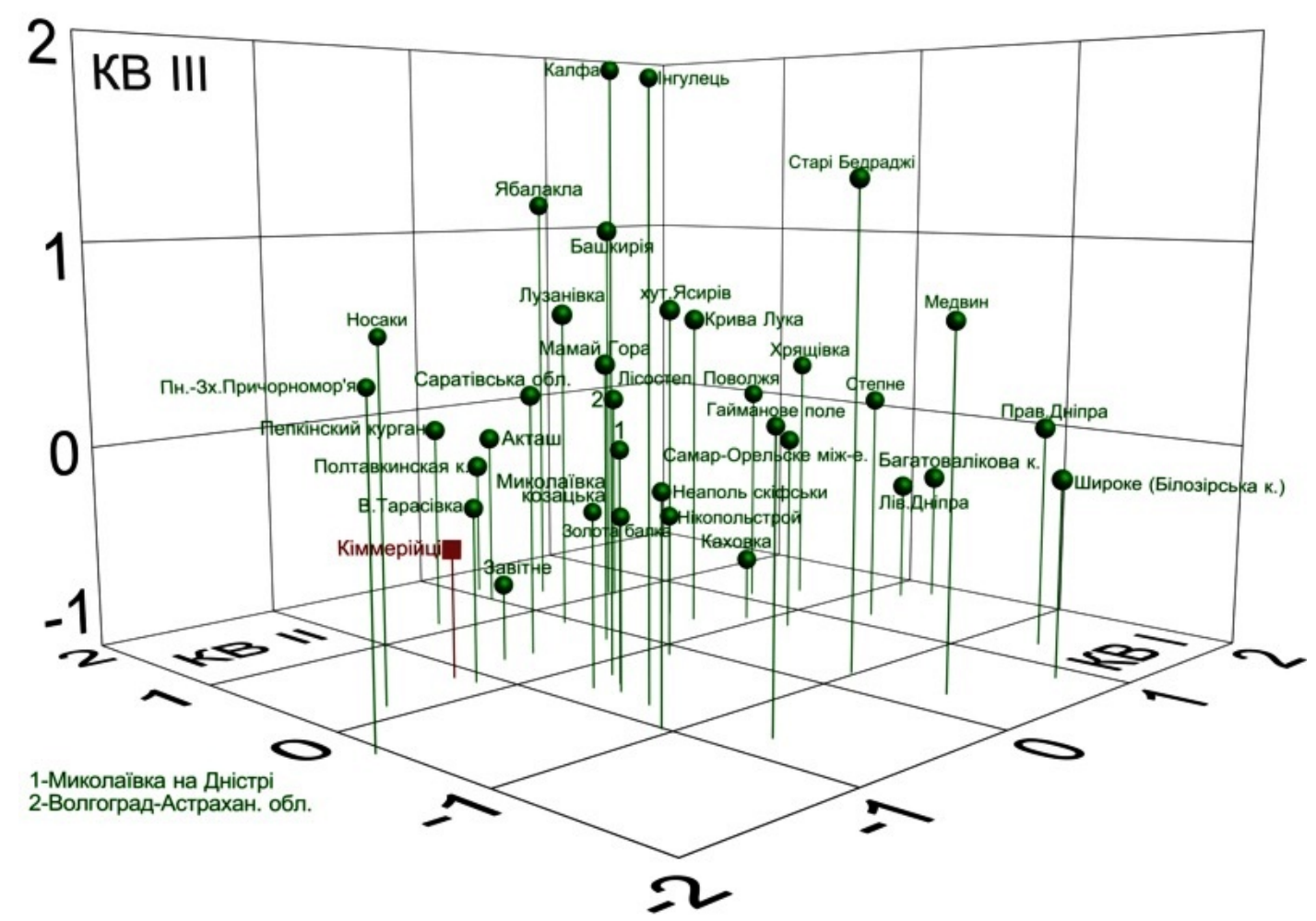

Рис. 6. Результати канонічного аналізу. Зіставлення 35 чоловічих груп IX-VIII cm. до н.е. зі збірною вибіркою кіммерійців (чорногорівський і новочеркаський етапи) у тривимірному nросторі.

Дискретно-варіативні ознаки. Фени: з 37 ознак на чоловічому черепі з кургану 1, пох. 3 (розкопки Північного гірничозбагачувального комбінату Кіровоградської обл.) було зафіксовано лише 8 фенів. Решта ймовірних дискретно-варіативних ознак не проявилися, тому записані як відсутні, що також є певним показником. Подаємо перелік фенів в анатомічному порядку. NORMA FACIALIS: одразу над орбітою ліворуч виявлено один отвір Foramina supraorbitale; під правою орбітою зафіксовано додатковий підорбітний отвір (Foramina infraorbitale accessorium) великого розміру. NORMA LATERALIS: на вилиці з обох боків Spina processus frontalis ossis zygomatici прямої форми. NORMA BASILARIS: форма поперечного піднебінного шва Sutura palatina transversa ламана; ліворуч на черепі виявлено задньовиростковий отвір (Canalis condylaris).

Етнічна краніоскопія. Оскільки потиличний індекс вираховується на групах, можна тільки констатувати брак кістки потилично-соскоподібного шва, а також, 3 обох боків вормієвої кістки у нижній частині лямбдоподібного шва L3. Такі дані на черепі вказують на його європеоїдність.

Піднебінний поперечний шов. Індекс поперечно-піднебінного шва (ІППШ) можна підрахувати тільки за наявності серії (14 спостережень однієї ознаки). У нашому випадку праворуч гілка ППШ робить такий вигин уперед, що на ній $є$ точки, які розміщуються попереду від передньої з двох крайніх, тому варіант позначався - I з літерою «а» (від «anterion»). А ліворуч від піднебіння зафіксовано варіант ІІа, притаманний більше монголоїдним популяціям. 


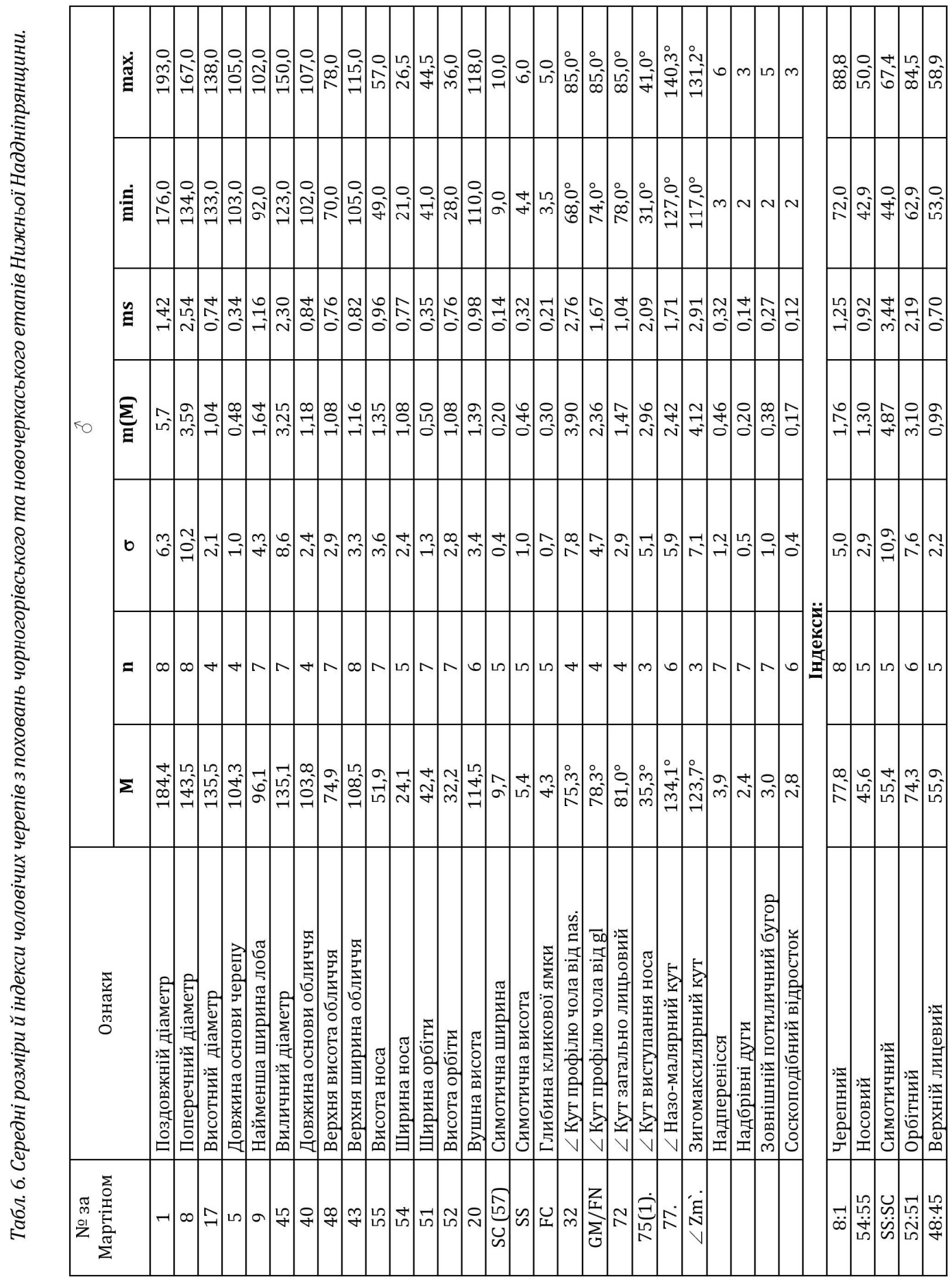


Підорбітний візерунок (ПОВ) з обох боків орбіти зафіксовано як тип II. Таким чином, можна описати ознаку: підорбітний візерунок на черепі як рису, притаманну північним популяціям, але такі висновки затверджуються тільки за наявності більшої відсоткової частоти у серії. На одному черепі слід рахувати ознаки у комплексі.

Клиноподібний верхньощелепний шов загалом трапляється частіше в європеоїдів, ніж у монголоїдів ${ }^{91}$. На чоловічому черепі з кургану 1, пох. 3, клиноподібний верхньощелепний шов відсутній на всіх чотирьох спостереженнях.

Виличного шва немає з обох боків вилиці.

Отже, за шістьма ознаками етнічної краніоскопї̈, досліджуваному черепові притаманно більше європеоїдних ознак.

\section{Висновки.}

Проведений аналіз дає змогу зробити наступні висновки:

1. Виявлено, що поховання 3 з кургану 1 чорногорівського етапу належіть чоловікові 30-40 років. Череп характеризується мезокранною черепною коробкою, помірним висотно-поздовжнім і висотно-поперечним індексами, великою довжиною основи черепа, помірно широкою потилицею. За лінійними розмірами обличчя мезогнатне, дуже високе та широке. За верхньолицевим індексом, обличчя вузьке. За загальним лицевим індексом - вузьке. Назомалярний і зигомаксилярні кути помірні, що свідчить про середньо профільоване обличчя на верхньому та середньому рівнях. Орбіти низькі. Ніс вузький, різко випнутий щодо лінії профілю обличчя. За симотичним покажчиком перенісся дуже високе.

2. За шістьма ознаками етнічної краніоскопії, досліджуваному черепу притаманно більше європеоїдних ознак.

3. При порівнянні окремих кіммерійських черепів методом головних компонент, досліджуваний череп з пох. 3, кургану 1 виявився подібним до мезокранного черепа з пох. 2, Запорізької обл. (Степове, курган 9).

4. Новостворена кіммерійська група чорногорівського етапу (IX-VIII ст. до н.е.) у середньому характеризується мезокранною, помірно високою черепною коробкою. Довжина основи черепа велика, лоб - помірно широкий. Обличчя мезогнатне, високе, помірно широке за виличним діаметром і вузьке - за верхнім лицевим індексом. На верхньому та середньому рівні обличчя дуже сильно профільоване. Відносна ширина орбіт помірна. Ніс вузький, кут його випинання - дуже великий. Перенісся високе.

5. У цілому, за даними краніометрії (метод канонічного багатовимірного аналізу), збірна кіммерійська група подібна до серії черепів з Верхньої Тарасівки.

6. Загальна вибірка чорногорівського та новочеркаського етапу з залученням дослідженого черепа з пох. 3 кургану 1 характеризується мезокранною, помірно високою черепною коробкою. Обличчя мезогнатне, помірно широке та високе, різко профільоване. Орбіти низькі, ніс вузький, перенісся високе, ніс випнутий дуже сильно.

7. Після канонічного багатовимірного порівняльного аналізу загальна вибірка чорногорівського та новочеркаського етапу повторно виявила подібність до черепів скіфської групи з Верхньої Тарасівки.

91 Козинцев А.Г. Этническая краниоскопия... С. 55. 
Подяка. Висловлюю подяку М.М. Дараган за можливість опрацьовувати череп із кургану 1, поховання 3 та надані консультації.

\section{REFERENCES}

Abinder, N. (1960). Transverzalnaia uploshchennost licevogo skeleta [Transversal Flattening of Facial Skeleton]. Trudy instituta etnografii AN SSSR, 50, 153-178 [in Russian].

Alekseev, V. \& Debec, G. (1964). Kraniometriia. Metodika antropologicheskih issledovanii [Craniometry. Methods of Anthropological Studies]. Moskva: Nauka [in Russian].

Berry, A.C. \& Berry, R.J. (1967). Epigenetic Variation in the Human Cranium. Journal Anat, 101, 361379.

Buxton, L.H.D. \& Morant, G.D. (1933). Essential Craniological Technique. Journal Royal Anthropological Institute, 63, 19-47.

Brothwell, D.R. (1972). Digging up Bones. London.

Chernyh, L.A. \& Daragan, M.N. (2014). Kurgany epohi eneolita - bronzy mezhdurechia Bazavluk - Solenaia - Chertomlyk [Burial Mounds of Copper and Bronze Ages Between the Rivers Bazavluk, Solenaja and Chertomlyk]. Kiev: Oleg Filiuk [in Russian].

Fabritsius, I.V. (1929). Tzareva mogila. In Eurosia Septent riokolis Antigua (pp. 126-134). Helsinki [in Finnish].

Gerasimov, M.M. (1949). Rekonstrukciia lica po cherepu iz grobnicy № 4 [Facial Reconstruction of the Skull from Entombment № 4]. In Rybakov B.A. Drevnosti Chernigova. Materialy i issledovaniia po arheologii drevnerusskih gorodov, 1, 99-102, prilozhenie 2 [in Russian].

Gerasimov, M.M. (1958). Cherepa iz pogrebenii srubnoi kultury v Srednem Povolzhe [Skulls from the Entombments of Timber-grave culture in Central Volga Region]. Kratkie soobshheniia instituta istorii materialnoi kultury, 71, 72-77 [in Russian].

Glazkova, N.M. \& Chtecov, V.P. (1960). Paleoantropologicheskie materialy Nizhnevolzhskogo otriada Stalingradskoi ekspedicii [Paleoanthropological Materials of Nizhnevolzhsky detachment of Stalingrad Expedition]. Materialy i issledovaniia po arheologii, 78, 285-292 [in Russian].

Grakov, B.N. (1971). Skify [Skythians]. Moskva [in Russian].

Grakov, B.M. (1949). Informatsiinyi zvit Nikopolskoi arkheolohichnoi ekspedytsii za 1946 r. [Informational Report of Nikopol Archaeological Expedition in 1946]. Arkheolohichni pamiatky URSR, II, 112115 [in Ukrainian].

Grakov, B.M. (1947). Skify [Skythians]. Kyiv [in Ukrainian].

Danylenko, V.N. (1951). Do kimmeriiskoi problemy (U zviazku z opublikuvanniam stely iz s. Natalivky) [About the Cimmerian Problem (Due to Publishing of Stele from Natalivka Village)]. Arkheolohiia, V, 218 [in Ukrainian].

Deriabin, V.E. (2008). Kurs lekcii po mnogomernoi biometrii dlia antropologov [Course of Lectures on Multidimensional Antrhopology for Anthropologists]. Moskva: MGU, biologicheskii fakultet [in Russian].

Diakonov, I.M. (1956). Istoriia Midii ot drevneishih vremion do konca IV v. do n.e [History of Media from Prehistoric Period Until Late 4th Cent. B. C.]. Moskva-Leningrad: Izdatelstvo Akademii nauk SSSR [in Russian].

Dubovskaia, 0.Z. (1987). O lokalnyh osobennostiah v inventare chornogorovskih pogrebenii [About Local Features in the Inventory of Chornohoriv Entombments]. In Tezizy dokladov oblasnogo nauchno-prakticheskogo seminara «Problemy ohrany i issledovaniia pamiatnikov arheologii v Donbasse» (pp. 75-77). Doneck [in Russian].

Efimova, S.G. (2000). Sootnoshenie lesostepnyh i stepnyh grupp naseleniia Evropeiskoi Skifii po dannym kraniologii [Correlation of Forest Steppe and Steppe Groups of European Skythia Poulation according to Craniological Data]. In Skify i sarmaty v VII-III vv. do n.e.: paleoekologiia, antropologiia $i$ arheologiia. Moskva [in Russian].

Konduktorova, T.S. (1979). Fizicheskii tip liudei Nizhnego Pridneprovia (po materialam mogilnika Nikolaevka-Kozackoe) [Physical Type of People from Lower Dnipro Region (According to Materials from Burial Ground Nikolaevka-Kozackoe)]. Moskva: Nauka [in Russian].

Konduktorova, T.S. (1964). Naselennia Neapolia Skifskoho za antropolohichnymy danymy [Population of Neapol Skythian According to Anthropological Data]. Materialy z antropolohii Ukrainy, 3, 32-71 [in Ukrainian].

Kozincev, A.G. (1980). Diskretnye priznaki na cherepah epohi bronzy iz Iuzhnoi Sibiri. K problemam metodiki izucheniia kraniologicheskogo polimorfizma [Discrete Features on the Bronze Age Skulls 
from Southern Siberia. About the Problems of Methods in Studies of Craniological Polymorphism]. In Issledovaniia po paleoantropologii i kraniologii SSSR (pp. 75-99). Moskva [in Russian].

Kozincev, A.G. (1988). Etnicheskaia kranioskopiia: rasovaia izmenchivost shvov cherepa sovremennogo cheloveka [Ethnical Cranioscopy: Race Variability of Cranial Sutures of Modern People]. Leningrad: Nauka [in Russian].

Kruc, S.I. (2002). Antropologicheskie dannye k kimmeriiskoi probleme [Anthropological Data to Cimmerian Problem]. Arheolohiia, 4, 13-29 [in Russian and Ukrainian].

Kruc, S.I. (1997). Antropologiia Steblevskogo mogilnika (k voprosu o fizicheskom tipe naseleniia lesostepi v skifskoe vremia) [Antrhopology of Steblev Burial Ground (About Physical Type of Forest Steppe Population in Scythian Period)]. In Skoryi, SA. Steblev: Skifskii mogilnik v Porose (pp. 91-116, prilozhenie 2). Kiev [in Russian].

Kruc, S.I. (1984). Paleoantropologicheskie issledovaniia Stepnogo Podneprovia (epoha bronzy) [Paleoanthropological Studies of Steppe Dnipro Region (Bronze Age)]. Kiev: Naukova dumka [in Russian].

Kruc, S.I. (1982). Paleoantropologicheskie materialy iz kurgana Zheltokamenka [Paleoanthropological Materials from Burial Mound Zheltokamenka]. In Drevnosti stepnoi Skifii (pp. 151-157). Kiev [in Russian].

Kruc, S.I. (2017). Skify stepei Ukrainy po antropologicheskim dannym [Steppe Skythians According to Anthropological Data]. In Kurgany Ukrainy, 5 (pp. 85-99). Kiev-Berlin [in Russian].

Kruc, V.A. (1977). Pozdnetripolskie pamiatniki Srednego Podneprovia [Late Trypillia Artefacts from Central Dnipro Region]. Kiev: Naukova dumka [in Russian].

Krylova, L.P. (1971). Arkheolohichni rozkopky starodavnikh kurhaniv na Kryvorizhzhi v 1964-1966 rr. [Archaeological Excavations of Ancient Burial Mounds of Kryvyi Rih Region in 1964-1966]. In Nash krai (pp. 18-31). Dnipropetrovsk: Promin [in Ukrainian].

Lahodovska, O.F. (1953). Pamiatky usativskoho typu [Artefacts of Usativ Type]. Arkheolohiia, 8, 101 [in Ukrainian].

Litvinova, L.V. (1994). Antropologicheskie materialy skifskoi kultury iz Severo-Zapadnogo Prichernomoria [Anthropological Data of Scythian Culture from Northern-Western Black Sea Region]. In Olviia200. Tezisy dokladov medzhunarodnoi konferencii posviashhennoi dvuhsotletiiu arheologicheskogo otkrytiia Olvii (5-9 sentiabria 1994 g., s. Parutino) (pp. 79-80). Nikolaev [in Russian].

Litvinova, L.V. (2001). Antropologicheskij material iz mogilnika Mamai-Gora [Anthropological Data from Burial Ground Mamaj-Gora]. In Andruh, S.I. Mogilnik Mamai-Gora (pp. 246-271). Zaporozhe [in Russian].

Lukiashko, S.I. (1999). Predskifskii period na Nizhnem Donu [Pre-Skythian Period in Lower Don Region]. Azov: Azovskii kraevedcheskii muzei [in Russian].

Makhortyh, S.V. (1987). Skify na Kavkaze v VII-Vvv. do n.e. [Skythians of Caucasus in 7th - 5th Cent. B.C.]. (Candidate's thesis). Kiev [in Russian].

Makhortykh, S.V. (2008). Kultura ta istoriia kimmeriitsiv Pivnichnoho Prychornomoria [Culture and History of Cimmerians of Northern Black Sea Region]. (Doctor's thesis). Kyiv [in Russian].

Melnik, A.A. \& Romashko, V.A. (1990). Kimmeriiskie pogrebeniia Krivorozhia [Cimmerian Entombments of Kryvyi Rih Region]. In Issledovaniia po arheologii Podneprovia (pp. 71-76). Dnepropetrovsk: DGU [in Russian].

Melnik, K., ed. (1893). Katalog kollekcii drevnostei A.N. Pol v Ekaterinoslave [Catalogue of Antiquities Collection by A.N. Pol in Ekaterinoslav]. Kiev: Kulzhenko [in Russian].

Melnik, L.A. (1982). Antropologicheskaia harakteristika naseleniia Samaro-Orelskogo mezhdurechia v epohu bronzy [Anthropological Characteristic of Population of Region Between Samara and Orel Region in Bronze Age]. In Drevnosti Stepnogo Podneprovia (III-II tys. do n.e.) (pp. 76-88). Dnepropetrovsk [in Russian].

Melnyk, 0.0. \& Steblyna, I.0. (2012). Kurhany Kryvorizhzhia [Burial Mounds of Kryvyi Rih Region]. Kryvyi Rih [in Ukrainian].

Moiseev, V.G. (2004). Opyt integracii chetyreh sistem antropologicheskih priznakov (kraniometrii, kranioskopii, odontologii i dermatoglifiki) [Experience of Integration of Four Systems of Antrhopological Features (Craniometry, Cranioscopy, Odontology and Dermatoglyphics)]. In Paleoantropologiia, etnicheskaia antropologiia, etnogenez: K 75-letiiu Ili Yosifovicha Gohmana (pp.186-200). SanktPeterburg: RAN [in Russian].

Movsesian, A.A. (2005). Feneticheskii analiz v paleoantropologii v sviazi s problemami raso- i etnogeneza [Fenetic Analysys in Paleoanthropology Related to Problems of Race and Ethnic Genesis]. (Doctor's thesis). Moskva [in Russian].

Otroshchenko, V.V. (1994). O pogrebeniiah chernogorovskogo tipa v Nizhnem Podone. Istoriko- 
arheologicheskoe issledovanie v Azove i na Nizhnem Donu v 1993, 13, 103-117 [in Russian].

Otroshchenko, V.V. (1989). Osobennosti pogrebenii chernogorovskoi gruppy [Key Features of Entombments of Chernogorov Group]. In Problemy skifo-sarmatskoi arheologii Severnogo Prichernomoria. Tezisy dokladov (pp. 111-112). Zaporozhe [in Russian].

Pokas, P.M. \& Nazarova, T.A. \& Diachenko, V.D. (1988). Materialy po antropologii Aktashskogo mogilnika [Materials on the Anthopology of Aktash Burial Ground]. In Bessonova, S.S. Aktashskii mogilnik skifskogo vremeni $v$ Vostochnom Krymu (pp. 118-144). Kiev: Naukova dumka [in Russian].

Rassamakin, Yu.Ya. \& Budnykov, O.B. (1993). Problemy rannoho stepovoho eneolitu u svitli vyvchennia novykh pamiatok [Problems of Early Steppe Copper Age in the Light of New Sites Exploration]. Arkheolohiia, 3, 128-142 [in Ukrainian].

Romashko, V.A. (1992). Kimmeriiski skorcheni pokhovannia novocherkaskoi hrupy [Cimmerian Huddled Entombments of Novocherkask Group]. Arkheolohiia, 3, 60-65 [in Ukrainian].

Romashko, V.A. (1990). Peredskifskii period v pograniche lesostepi i stepi Dneprovskogo Levoberezhia (XII - nachalo VII vv. do n.e.) [Pre-Scythian Period on the Border of Forest-Steppe and Steppe on the Left Bank of Dnipro (12 ${ }^{\text {th }}-$ Early $7^{\text {th }}$ cent. B.C.)] (Extended abstract of Candidate's thesis). Kiev [in Russian].

Shevchenko, A.V. (1986). Antropologiia naseleniia yuzhnorusskih stepei v epohu bronzy [Anthropology of Population of South Russian Steppe in Bronze Age]. In Antropologiia sovremennogo i drevnego naseleniia evropeiskoi chasti SSSR (pp. 190-193). Leningrad: Nauka [in Russian].

Shramko, B.A. (1979). Kimmeriiskii vklad v kulturu skifskoi epohi [Cimmerian Contribution into Culture of Scythian Epoch]. In Problemy epohi bronzy yuga Vostochnoi Evropy: tezisy dokladov konferencii (pp. 12-13). Doneck [in Russian].

Skoryi, S.A. (1999). Kimmeriicy v ukrainskoi Lesostepi [Cimmerians in Ukrainian Forest Steppe]. KyivPoltava: Arheologiia [in Russian].

Terenozhkin, A.I. (1976). Kimmeriicy [Cimmerians]. Kiev: Naukova dumka [in Russian].

Vallois, H.V. (1937) La duree de la viechez l'home fossile. L'Anthropologie, 47, 499-532 [in French].

Velikanova, M.S. (1975). Paleoantropologiia Prutsko-Dnestrovskogo mezhdurechia [Paleoanthropology of the Region between Prut and Dnister Rivers]. Moskva: Nauka [in Russian].

Zhiliaeva-Kruc, S.I. (1970). Cherepa iz skifskih pogrebenii Kerchenskoi ekspedicii 1964-1967 gg. [Skulls from Scythian Entombments of Kerch Expedition in 1964-1967]. In Drevnosti Vostochnogo Kryma (pp. 180-189). Kiev: Naukova dumka [in Russian].

Zinevich, G.P. (1973). Antropologicheskie materialy srednevekovyh mogi'nikov Yugo-Zapadnogo Kryma [Anthropological Materials from Medieval Burial Grounds of South-Western Crimea]. Kiev: Naukova dumka [in Russian].

Zinevich, G.P. (1967). Ocherki paleoantropologii Ukrainy [Essays on Paleoanthropology of Ukraine]. Kiev: Naukova Dumka [in Russian].

Zinevych, G.P. (1971). Do antropolohii mohylnyka bilia s. Zavitne v Krymu [About Anthropology of Burial Ground near Zavitne Village in Crimea]. Materialy z antropolohii Ukrainy, 5, 111-121 [in Ukrainian].

\section{Yuriy Dolzhenko}

(Institute of Archaeology National Academy of Sciences of Ukraine, Kyiv, Ukraine)

ORCID: https://orcid.org/0000-0001-9807-2835

\section{Craniology of Cimmerian Population of Naddniprianschyna}

Just in the middle of the $20^{\text {th }}$ century the relevance of the Cimmerian problem for understanding the historical events that took place in the pre-Scythian and Scythian periods on the vast territory of the Black Sea region, became apparent, and that, in particular, was noted in the thesis of S.V. Machortykh for the academic degree of Doctor in Historical Science. In many cases, that was associated with the mentioning of the Cimmerians in written sources, and the researchers tried to match the historical Cimmerians with limited archaeological and anthropological materials, which in general were scarce. Thus, the study of the Cimmerian problem is relevant to understanding the laws of the development of European culture and history in $1000 \mathrm{BC}$. Many issues raised in historical science as far back as at the beginning of the $20^{\text {th }}$ century remain controversial nowadays as well. Therefore, every skull on the burial of this 
culture is an important source for research.

The goal of the paper is to compare the general Cimmerian group and a separate sample of Chornohorivka and Novocherkassk period with the series of Scythian culture according to the craniometry, using the method of canonical multivariate analysis.

According to craniological data, an individual characteristic of the skull from the mound 1, burial 3, found during the excavations of 0.0. Melnyk on the territory of the Northern Iron Ore Dressing Works of Kirovograd Region in 2007. It was found out that burial 3 from mound 1 dated back to the chornohorivka period and belonged to 30-40-year-old man. The skull is characterized by a mesocranial brainbox, medium altitude-longitudinal, and altitudelatitudinal indexes, increased cranial base length, moderately wide occiput. According to the linear dimensions the face is mesognathic, very long and broad. According to the upper face index, the face is narrow; according to the general face index, it is narrow. The nasomalar and zygomaxillary angles are moderate, indicating an average profiled face on the upper and middle levels. Orbits are low. The nose is narrow, sharply protruding the face profile line. According to the simotical index, the nasal bridge is very high. At the same time, discrete-variation features reflecting the genetic linkages in the population were studied. Thanks to the use of a multivariate analysis of the main components, it has been proved that the studied skull according to the five craniological features is most similar to the male skull from the burial site (mound 9, burial site 2) in Stepove of Zaporizhzhia Region. Separately, two series of Cimmerians of the chornohorivka period and a combined sample of the Chornohorivka and Novocherkassk periods with the involvement of that burial site were created. After a canonical multivariate comparative analysis, the general sample of the Chornohorivka and Novocherkassk periods showed the similarity to the skulls of the Scythian group from the Steppe Right Bank of the Dnipro - Verkhnia Tarasivka.

In the future, for objective research, it is necessary to accumulate anthropological material and increase the sample in order to deepen the conclusions on more representative materials.

Keywords: Cimmerian culture, craniology, paleoanthropology, craniometry, Kirovograd Region, skull, Chornohorivka period 